Bridging theory and practice: How creative ideas flourish through personal and academic literacy practices

Ketabi, Saeed

University of Isfahan, Isfahan, Iran (ketabi@fgn.ui.ac.ir)

Zabihi, Reza $₫$

University of Isfahan, Isfahan, Iran (zabihi@hotmail.com)

Ghadiri, Momene

University of Isfahan, Isfahan, Iran (momene.ghadiri@gmail.com)

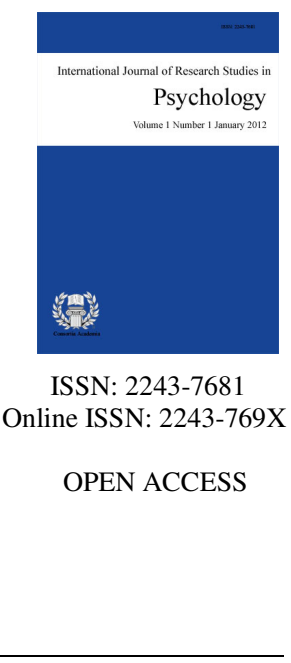

\title{
Abstract
}

One of the key life skills advocated by the World Health Organization (1999) to be incorporated into any curriculum is 'creativity'. With the advent of the notion of Applied ELT (Pishghadam, 2011), which considers ELT as an independent discipline now able to contribute to and enrich other domains of knowledge, the idea of life skills education was soon imported into the field of English language teaching. In this connection, it seems that figuring out ways to improve life skills, say, creativity in language learners should be given well-deserved attention. Be that as it may, this paper explores whether and to what extent reading and writing activities can provide abundant opportunities for creative ideas to flourish. Specifically, this study explored the extent to which extensive practice in academic and personal reading and/or writing would be related to high creative thinking. For this purpose, a sample of 300 intermediate EFL learners in Iran participated in this study by filling out a self-report questionnaire and completing the Abbreviated Torrance Test for Adults (ATTA). The questionnaire inquires about the total courses taken in reading and writing as well as the total hours spent on reading and writing in both L1 and L2. The results revealed that learners who spent more time on reading and writing had a significantly better performance on the creativity test. That is, creative thinking scores (fluency, originality, elaboration, flexibility, and the Creativity Index) showed significant correlations with the amount of time spent on reading and writing.

Keywords: applied ELT, psychology, creative thinking, reading and writing practice, Torrance, EFL learners 


\section{Bridging theory and practice: How creative ideas flourish through personal and academic literacy practices}

\section{Introduction}

It has often been argued that core life skills should be worked on in schools alongside other academic subjects (Matheson \& Grosvenor, 1999). In this respect, life skills are defined as "the abilities for adaptive and positive behavior that enable individuals to deal effectively with the demands and challenges of everyday life" (WHO, 1999). The essential life skills proposed by the World Health Organization include psychosocial and interpersonal competencies including, decision making, creative thinking, critical thinking, problem solving, interpersonal relationship skills, effective communication, self-awareness, empathy and understanding, coping with emotions and coping with stress. Several researchers and scholars (e.g., Brooks, 2001; Francis, 2007; Goody, 2001; Larson \& Cook, 1985; Matthews, 2006; Noddings, 2003; Radja, Hoffmann, \& Bakhshi, 2008; Spence, 2003; Walker, 1999) have asserted the importance of improving these skills in the context of education.

Recently, Pishghadam (2011) has introduced the theory of Applied ELT by which he maintains that ELT, by virtue of its interdisciplinary nature and scientific acceptability, has now gained the potentiality to be applied and contribute to other domains of knowledge such as psychology and sociology. Besides, thanks to the several distinctive features that ELT classes provide learners and teacher with, it can set the scene for the promotion of several life skills. Moreover, the idea was extended by the introduction of life syllabus based on which language teachers are recommended to give more precedence to life skills in ELT classes (Pishghadam \& Zabihi, 2012). Under this account, ELT professionals are henceforth liable for improving learners' whole-person growth, including both their intellectual development as well as other issues which are of prime importance in their lives. One of these issues which had recurrently been cited in the literature (Amabile, 1985; Guilford, 1981) as an essential skill in people's lives is 'creative thinking'.

In this respect, many complex problems at the individual, social and global levels have been found to be made soluble by creative abilities (e.g., Amabile, 1989; Brown, 1989; Guilford, 1981; Plucker, Beghetto, \& Dow, 2004). These abilities which include, among other abilities, the creation of ideas or products that are original, pertinent and useful (Amabile, 1996; Sternberg \& Lubart, 1996) and the ability to detect the problems, make guesses and create new ideas (Torrance, 1966, 1988), has for long been considered a core skill to be encouraged for everyone (Torrance, 1988; Taylor \& Sacks, 1981).

From a psychologist's point of view, for instance, creativity is an important factor by virtue of its potentiality for describing individuals and the differences between them. The examination of these individual particularities seems to be mandatory due to the fact that they can be used to predict individuals' future behavior. The studies done by Amabile and Csikszentmihalyi in the 1990s have found that once individuals become personally engaged and intrinsically motivated in creative practices, they can produce better work and follow more difficult and demanding tasks.

Under this account, this psychological construct has been on the leading edge of educational research for more than five decades (e.g., Atkinson, 2004; Naderi et al., 2009; Palaniappan, 2007; Struthers, Menec, Schonwetter, \& Perry, 1996). Given the critical importance of creative thinking in people's lives (Amabile, 1985; Guilford, 1981) as well as the normally distributed status of creative abilities among all people (Craft, 2001; Duffy, 1998; Feldman, 1999; Guilford, 1950; Harrington, Block, \& Block, 1983), and considering the fact that creativity can be enhanced through learning (Taylor \& Sacks, 1981; Torrance, 1988), it seems to us that extensive attempts should be made at finding those factors that can enhance creativity.

As one particular case in point, creativity as a thinking skill is closely associated with reading and writing 
Bridging theory and practice: How creative ideas flourish through personal and academic literacy practices

abilities (Wang, 2011); Moreover, granted the fact that thinking skills are highly related to the language development of learners (Vygotsky, 1986), one might argue that creativity is also in close connection with language-related activities such as reading and writing. Accordingly, several studies have shown that creative abilities can be enhanced through learning activities such as reading and writing (McVey, 2008; Sak, 2004; Scanlon, 2006; Smith, Paradice, \& Smith, 2000; Sturgell, 2008). As McVey (2008) points out, reading and writing abilities should be improved for "endless creative possibilities" (p. 294).

A plethora of studies have examined the extent to which classroom practices may help the promotion of creative thinking in students through practice in reading and writing (Messman, 1991; Otto, 1991; Sak, 2004). Furthermore, researchers such as Chen, Bernard, and Hsu (2005) and Zachopoulou, Trevlas, and Konstadinidou (2006) made attempts at devising a variety of reading and writing activities. All of these studies spouse the idea that the careful design and implementation of reading and writing activities is needed on the part of materials developers and syllabus designers to boost students' creation of novel ideas. Nonetheless, there seems to be lack of evidence as to the role of both academic and personal reading and writing practices in the enhancement of learners' creativity. Hence, the primary aim of this paper is to see whether academic and personal reading and/or writing activities (both in L1 and L2) are associated with creative performance of EFL (English as a Foreign Language) learners in Iran.

\section{Conceptual Framework}

\subsection{On the Definition of Creative Thinking}

Due to the importance of creativity, several researchers to date have strived hard to figure out the nature of creativity as well as the ways through which it can be enhanced (e.g., Plucker, Beghetto, \& Dow, 2004; Runco, 2004); likewise, many scholars have developed and followed certain theories of creativity (e.g., Csikszentmihalyi, 1988; Maslow, 1968; Sternberg \& Lubart, 1996). Moreover, many others have devised instruments for the measurement of creativity (e.g., Meeker, 1985; Sternberg, 1997; Torrance, 1988; Urban \& Jellen, 1996). However, as Brown, (1989) and Lubart (1994) have pointed out, creativity encompasses a broad range of distinct but interrelated realities; so there cannot be a single definition of creativity (Dörnyei, 2005) unless one narrows down the scope of investigation and stipulates, in advance, the aspect of creativity that should be examined.

In this connection, Duffy (1998) refers to creativity as one's ability to look at things from new and original perspectives, to transfer the gained experience to new situations, to think in unconventional and idiosyncratic ways and to use novel approaches to problem solving and making original things. Also, it encompasses evaluative ability, problem sensitivity, production fluency, idea novelty, flexibility of mind, synthesizing and analyzing capability, conceptual structure complexity and reorganization or redefinition of organized wholes (Guilford, 1950). As mentioned earlier, Torrance (1988) and Taylor and Sacks (1981) considered creativity as a traits which is normally distributed in the population. With that in mind, Torrance (1988) considered creativity as the ability to identify problems, make guesses, generate new ideas, and communicate the results.

\subsection{On the Factors that Enhance Creativity}

Several people such as Niu and Sternberg (2003) and Rudowicz, Lok, and Kitto (1995) have pointed to the fact that creative abilities can be influenced by cultural and educational factors. Moreover, teaching activities have been found to boost students' creative thinking (e.g., Neethling, 2000; Torrance, 1988). Generally, studies on creativity have identified the various factors that should be encouraged and improved by teachers; these include cognitive factors (Cropley, 1992; Pollert, Feldhusen, Van Mondfrans, \& Treffinger, 1969), motivation factors (Beghetto, 2005; Cropley, 1997; Torrance, 1992), personality factors (Amabile, 1996; Beghetto, 2005; Cannatella, 2004; Gardner, 1988; Von Eschenbach \& Noland, 1981), and social factors (Cropley, 1992, Torrance, 1992). 


\subsection{On the Relevance of Reading/Writing Practice and Creativity}

As a thinking skill, creativity is closely connected with reading and writing abilities (Wang, 2011); Further, due to the fact that thinking skills are highly related to the language development of learners (Piaget, 2002; Vygotsky, 1986), one might argue that creativity is also in close connection with language-related activities such as reading and writing. The abilities that are involved with reading and writing seem to have similar features that creativity researchers suggest enhance creative thinking, such as the freedom and ability to exchange ideas (Beghetto, 2005; Torrance, 1992), a focus on self-disclosure (Amabile, 1996), and attention to the individual (Harrington, Block, \& Block, 1987). Moreover, several features that foster creative thinking can be improved through reading or writing activities such as thinking, inspecting, curiosity, and freedom to express oneself.

Practice in reading and writing seems to be in close connection with practices that enhance creative thinking. This is primarily due to the fact that reading and writing typically require not only analytical, critical, and self-expressive abilities, but also a feeling of self-disclosure. Besides, it has been argued that reading materials provide exclusive opportunities for the development of creative ideas (Sturgell, 2008) and that writing practices are creative per se (McVey, 2008). In this connection, several researchers have devised specific creativity programs through reading and writing activities (e.g., Chen et al., 2005; Zachopoulou et al., 2006). Under this account, many studies have consistently shown that creativity can be promoted through learning activities such as reading and writing (McVey, 2008; Sak, 2004; Scanlon, 2006; Smith, Paradice, \& Smith, 2000; Sturgell, 2008). However, there seems to be little evidence as to the impact of both academic and personal reading and writing practices in the promotion of learners' creative thinking abilities. Therefore, the main objective of this study is to see whether academic and personal reading and/or writing activities (both in L1 and L2) are associated with creative performance of EFL (English as a Foreign Language) learners in Iran. It intends to answer the following questions: (a) Do learners with different reading or writing habits, such as reading books or reading online, perform differently on a creativity test? (b) Does spending more hours on reading/writing in learners' L1 and L2 enhance learners' creative performance?

\section{Method}

\subsection{Participants and design}

Considering the fact that the purpose of this study was to determine if there is any significant correlation between practice in reading and writing and creative test performance, a correlational design was used to collect and analyze the data. A correlational design best suits the present study since it allows variables to show if they have a positive or negative relationship. Three hundred male and female EFL learners in Iran voluntarily took part in the study. Their ages ranged from 16 to 28. Based on a version of an Oxford Placement Test (OPT), intermediate-level learners were selected for the study. The test contained 60 multiple choice items, and it was used to enable the researchers to control the language proficiency of the learners. This test consisted of grammar (20 items), vocabulary (20 items), reading comprehension (20 items) together with a writing section. The allotted time for answering the questions was 45 minutes. After correcting the papers, 104 learners were selected as the intermediate group based on the OPT manual.

\subsection{Procedure and Instruments}

Upon administering and homogenizing the participants on the OPT test, two instruments were employed: A test of creativity and a questionnaire. Considering the fact that the participants in this study were young adults in Iran, the Abbreviated Torrance Test for Adults (ATTA, Goff \& Torrance, 2002) was selected for measuring creativity. The ATTA is a shortened version of the Torrance Test of Creative Thinking (TTCT) and has been commonly utilized by several researchers (e.g., Kharkhurin, 2008; Lin, Hsu, Chen, \& Wang, 2011; Meintjes \& Grosser, 2010; Rosenthal, DeMers, Stilwell, Graybeal, \& Zins, 1983; Runco \& Albert, 1985; Wang, 2011). 
Bridging theory and practice: How creative ideas flourish through personal and academic literacy practices

The ATTA measures the number of ideas the learner can produce within a particular time period (fluency), the extent to which these ideas are unique (originality), the number of details that the learner can add to the original idea (elaboration) and how many varieties of ideas can be produced for solving a problem (flexibility). It comprises three tests: one verbal and two figural tests. In order to solve problems or communicate ideas, within a particular time period, the learners are expected to recognize problems, make guesses, and generate ideas by writing phrases or sentences and by drawing pictures. The Creativity Index is ranked with seven levels whose values range from 1 to 7 ( 1 = Minimal; $2=$ Low; 3 = Below Average; $4=$ Average; $5=$ Above Average; $6=$ High; 7 = Substantial). The test has proved to be as reliable and valid as the TTCT (Goff \& Torrance, 2000; Kim, 2006; McCann, 2005; Runco, Dow, \& Smith, 2006; Torrance, 2000). It takes about 15 minutes to complete. Goff and Torrance (2002) have reported a reliability of 0.90 for the Creativity Index, using a KR-21 reliability coefficient.

The other instrument used in the present study was a questionnaire inquiring about (a) estimated hours spent on a variety of reading and writing activities; and (b) demographic information. The self-reported hours spent on various reading and writing activities were measured with a Likert scale of 6 points $(1=$ never; $2=$ less than one hour per week; $3=1-5$ hours per week; $4=6$-10 hours per week; $5=11$-15 hours per week; $6=$ more than 15 hours per week). In addition, the reading activities included (a) reading textbooks, (b) reading books for pleasure, (c) reading magazines or articles, (d) reading newspapers, (e) online news, and (f) reading blogs. Further, writing activities comprised (a) writing their essays, (b) writing articles for fun, (c) writing personal diaries, and (d) writing personal blogs. All activities were considered in both the L1 and L2 of the learners.

\section{Results}

The statistical program SPSS was utilized in order to organize and compile the collected data. In the present study, 300 surveys and tests of creativity were collected. Among these, the data regarding 104 participants were relevant to the aims of this study. The Pearson product-moment correlation analysis was applied to the data in order to examine the significant relationships among the variables under investigation: (1) the relationship between creativity scores and hours spent on different reading activities in Persian and English; (2) the relationship between creativity scores and hours spent on different writing activities in Persian and English.

\subsection{Creativity and hours on different reading activities}

As for the hours spent on different reading activities, significant correlations were found between creative ability and the hours spent on the following activities: (1) reading English books for fun (fluency: $r=0.212$; elaboration: $r=0.268$ ); (2) reading online news (originality: $r=0.291$; CI: $r=0.262$ ); (3) reading Persian books (fluency: $r=0.266$; originality: $r=0.244$; elaboration: $r=0.284$; $\mathrm{CI}: \mathrm{r}=0.248$ ); (4) reading magazines in Persian (fluency: $r=0.220$; originality: $r=0.214$; elaboration: $r=0.256 ; \mathrm{CI}: r=0.241$ ); (5) reading newspapers in Persian (originality $r=0.171$ ); and (6) reading blogs in Persian (fluency: $r=0.282$; originality: $r=0.205 ; C I: r=$ 0.216). Table 1 demonstrates the detailed correlations. Nonetheless, self-evaluated hours spent on some reading activities did not affect learners' creative performance, e.g., reading magazines/newspapers/blogs in English and reading textbooks/newspapers/online news in Persian.

\subsection{Creativity and hours on different writing activities}

With respect to the hours spent on different writing activities, significant correlations were also found between creative ability and the hours spent on the following activities: (1) writing personal diaries in Persian (fluency: $r=0.150, p<.05$ ); and (2) writing personal blogs in English (originality: $r=0.171$; flexibility: $r=$ 0.154; CI: $r=0.183$ ). Table 2 demonstrates the detailed correlations. However, self-reported hours spent on some writing activities did not bear any relationship with learners' creative performance, e.g., writing essay assignments in English and Persian and writing articles for fun in English and Persian. 
Ketabi, S., Zabihi, R., \& Ghadiri, M.

\section{Table 1}

Correlations between creativity and hours on different reading activities

\begin{tabular}{|c|c|c|}
\hline No. & Reading Activities & Correlation \\
\hline \multirow[t]{3}{*}{1} & Hours on reading English books for fun & \\
\hline & Fluency & $0.212 *$ \\
\hline & Elaboration & $0.268 * *$ \\
\hline \multirow[t]{3}{*}{2} & Hours on reading online news & \\
\hline & Originality & $291 * *$ \\
\hline & $\mathrm{CI}$ & $262 * *$ \\
\hline \multirow[t]{5}{*}{3} & Hours on reading Persian books & \\
\hline & Fluency & $0.266 * *$ \\
\hline & Originality & $0.244 * *$ \\
\hline & Elaboration & $0.284 * *$ \\
\hline & $\mathrm{CI}$ & $0.248 * *$ \\
\hline \multirow[t]{5}{*}{4} & Hours on reading magazines in Persian & \\
\hline & Fluency & $0.220 *$ \\
\hline & Originality & $0.214 *$ \\
\hline & Elaboration & $0.256 * *$ \\
\hline & $\mathrm{CI}$ & $0.241 * *$ \\
\hline \multirow[t]{2}{*}{5} & Hours on reading newspapers in Persian & \\
\hline & Originality & $0.171 *$ \\
\hline \multirow[t]{4}{*}{6} & Hours on reading blogs in Persian & \\
\hline & Fluency & $0.282 * *$ \\
\hline & Originality & $0.205^{*}$ \\
\hline & CI & $0216 *$ \\
\hline
\end{tabular}

\section{Table 2}

Correlations between creativity and hours on different reading activities

\begin{tabular}{|c|c|c|}
\hline No. & Reading Activities & Correlation \\
\hline \multirow[t]{2}{*}{1} & Hours on writing personal diaries in Persian & \\
\hline & Fluency & $0.150 *$ \\
\hline \multirow[t]{4}{*}{2} & Hours on writing personal blogs in English & \\
\hline & Originality & $0.171 *$ \\
\hline & Flexibility & $0.154 *$ \\
\hline & $\mathrm{CI}$ & $0.183 * *$ \\
\hline
\end{tabular}

\section{Discussion}

The findings of this study lend great support to the claim that reading and writing practices can influence creative abilities (Wang, 2011). These results are also in line with those of other studies (e.g., McVey, 2008; Sak, 2004; Scanlon, 2006; Smith, Paradice, \& Smith, 2000; Sturgell, 2008). Moreover, granted that thinking skills are closely related to the language development of learners (Piaget, 2002; Vygotsky, 1986), one might argue that creative abilities is also in close connection with language-related activities such as reading and writing. In this connection, it is worth noting that the abilities that are involved in reading and writing practices seem to have similar characteristics that researchers in the domain of creativity suggest improve creative thinking, such as the freedom and ability to exchange ideas (Beghetto, 2005; Torrance, 1992), a focus on self-disclosure (Amabile, 1996), and attention to the individual (Harrington, Block, \& Block, 1987). Besides, many features that may boost creativity may be enriched through reading or writing activities such as thinking, inspecting, curiosity, and freedom to express oneself.

Overall, it was found that those participants who spent more time on reading and writing obtained higher 
Bridging theory and practice: How creative ideas flourish through personal and academic literacy practices

scores on the creativity test. As a case in point, among these dimensions, creative fluency correlated with the amount of time spent on several reading activities such as reading English books for fun, reading Persian books, reading magazines in Persian, and reading blogs in Persian. Such a general conclusion is justifiable in the sense that fluency refers to the number of ideas the learner can produce within a particular time period; such ability may be achieved by these activities, considering the fact that reading books, magazines, and blogs can help learners come up with a greater number of ideas.

In the significant correlations that were found between creative abilities and hours spent on reading/writing practices, the ability of elaboration and originality constantly emerge as the most prominent and constant interaction. This finding suggests that academic and personal practices in L1/L2 reading and writing have significant and positive relationships with the ability of elaboration and originality. Elaboration is the ability of individuals to garnish ideas with details (Goff \& Torrance, 2002). According Further, reading and writing activities have a significant and positive relationship with the ability to develop original ideas with details. However, flexibility seems to bear the least relationship with reading/writing practices identified in this study.

All in all, the findings obtained concerning the interface between creativity measures and the amount of time spent on L1/L2 reading and writing activities may contribute to making pedagogical decisions and can help materials developers, syllabus designers and language teachers revisit the selection and implementation of language teaching tasks. Accordingly, the ELT professionals should include reading and writing activities that enhance creativity. As Pishghadam and Zabihi (2012) have pointed out, specific textbooks should be developed with the purpose of enhancing learners' creativity. To give but one example, they may choose to include reading and writing activities which require a high degree of imagination and generation of novel ideas. The authors hope that outlooks on language teaching change by helping language teachers to adopt a new role (Pishghadam, Zabihi, \& Kermanshahi, 2012); that is, they should become educational language teachers who are able not only to achieve excellence in language teaching but also to gain adequate knowledge of other domains of knowledge such as psychology.

\section{Conclusion}

As one of the presumptions of Applied ELT, English language classes should be considered cites where learners' life skills can be improved; thus, a defining role should be assigned to the professionals of ELT for the integration of life skills training into English education. The present study clearly demonstrated the nexus between L1/L2 literacy practices and learners' creative thinking ability. Therefore, the main task before ELT syllabus designers and materials developers is to mix creativity with language learning in order to make ELT more meaningful. Taken together, language teachers are expected not only to be experts in language teaching, but they should also have a fair knowledge of the subcomponents of creativity such as fluency, originality, elaboration, and flexibility, as well as the different techniques for their enhancement.

Under these accounts, some recommendations from the results of this study can be summarized as follows. First, given the high potentiality of ELT to contribute to the field of psychology (Pishghadam, 2011), not to mention the significant and positive correlations found in this study, the ELT professionals should recognize the necessity of teaching creative abilities explicitly in language classes and pave the way for the inclusion of creativity courses in to the whole ELT curriculum. Second, English teachers should introduce, and be introduced to, the different techniques and literacy materials that help facilitate the improvement of learners' creative thinking abilities. Finally, due to the interdisciplinary nature of ELT, it is recommended that there should be a close interaction between English practitioners and psychologists to provide abundant opportunities in order for creative ideas to flourish.

\section{References:}

Amabile, T. M. (1985). The social psychology of creativity: A componential conceptualization. Journal of 
Ketabi, S., Zabihi, R., \& Ghadiri, M.

Personality and Social Science, 45(22), 357-376.

Amabile, T. M. (1989). Growing up creative: Nurturing a lifetime of creativity. New York: Crown. Amabile, T. M. (1996). Creativity in context. Boulder, CO: Westview Press.

Atkinson, S. (2004). A comparison of the relationship between creativity, learning style preference and achievement at GCSE and degree level in the context of design and technology project work. DATA International Research Conference on Creativity and Innovation, Sunderland University, England.

Beghetto, R. A. (2005). Does assessment kill student creativity? The Educational Forum, 69(2), 254-263. http://dx.doi.org/10.1080/00131720508984694

Brooks, R. (2001) Fostering motivation, hope, and resilience in children with learning disorders. Annals of Dyslexia, 51, 9-20. http://dx.doi.org/10.1007/s11881-001-0003-4

Brown, R. T. (1989). Creativity: What are we measure? In J. A. Glover, R. R. Ronning, \& C. R. Reynolds (Eds.), Handbook of creativity (pp. 3-32). New York: Plenum.

Cannatella, H. (2004). Embedding creativity in teaching and learning. Journal of Aesthetic Education, 38(4), 59-70.

Chen, C., Bernard, J., \& Hsu, K. (2005). An empirical study of industrial engineering and management curriculum reform in fostering students' creativity. European Journal of Engineering Education, 30(2), 191-202. http://dx.doi.org/10.1080/03043790500087423

Craft, A. (2001). Little c creativity. In A. Craft, B. Jeffrey, \& M. Leibling (Eds.), Creativity in education. London: Continuum.

Cropley, A. J. (1992). More ways than one: Fostering creativity in the classroom. Norwood, NJ: Ablex.

Cropley, A. J. (1997). Fostering creativity in the classroom. In M. A. Runco (Ed.), The creativity research handbook (pp. 83-114). Cresskill, NJ: Hampton Press.

Csikszentmihalyi, M. (1988). Society, culture, and person: A systems view of creativity. In R. J. Sternberg (Ed.), The nature of creativity: Contemporary psychological perspectives (pp. 325-339). New York: Cambridge University Press.

Dornyei, Z. (2005). The psychology of the language learner: Individual differences in second language acquisition. Mahwah, NJ: Lawrence Erlbaum.

Duffy, B. (1998). Supporting creativity and imagination in the early years. Buckingham: Open University Press.

Feldman, D. H. (1999). The development of creativity. In R. J. Sternberg (Ed.), Handbook of creativity. Cambridge: Cambridge University Press.

Francis, M. (2007). Life skills education. www.changingminds.org.

Gardner, H. (1988). Creativity: An interdisciplinary perspective. Creative Research Journal, 1, 8-26. http://dx.doi.org/10.1080/10400418809534284

Goff, K., \& Torrance, E. P. (2000). Brief demonstrator form of the Torrance tests of creative thinking: Training/teaching manual for adults with technical data. Bensenville, IL: Scholastic Testing Service, Inc.

Goff, K., \& Torrance, E. P. (2002). Abbreviated Torrance test for adults manual. Bensenville, IL: Scholastic Testing Service, Inc.

Goody, J. (2001). Competencies and education: Contextual diversity. In: D. S. Rychen, \& L.H. Salganik (Eds.), Defining and selecting key competencies. Gottingen, Hogrefe and Huber Publications.

Guilford, J. P. (1950). Creativity. American Psychologist, 5, 444-454. http://dx.doi.org/10.1037/h0063487

Guilford, J. P. (1981). Factors that aid and hinder creativity. In J. C. Gowan, J. Khatena, \& E. P. Torrance (Eds.), Creativity: Its educational implications. Iowa: Kendall.

Harrington, D. M., Block, J., \& Block, J. H. (1983). Predicting creativity in preadolescence from divergent thinking in early childhood. Journal of Personality and Social Psychology, 45, 609-623. http://dx.doi.org/10.1037/0022-3514.45.3.609

Kharkhurin, A. V. (2008). The effect of linguistic proficiency, age of second language acquisition, and length of exposure to a new cultural environment on bilinguals' divergent thinking. Bilingualism: Language and Cognition, 11 (2), 225-243.

Kim, K. H. (2006). Can we trust creativity tests: A review of the Torrance Tests of Creative Thinking. Creativity 
Bridging theory and practice: How creative ideas flourish through personal and academic literacy practices

Research Journal, 18, 3-14. http://dx.doi.org/10.1207/s15326934crj1801_2

Larson, D. G., \& Cook, R. E. (1985). Life-skills training in education. Journal of Group Psychotherapy, Psychodrama, \& Sociometry, 38(1), 11-22.

Lin, W.L., Hsu, K.Y., Chen, H.C., \& Wang, J.W. (2011). The relations of gender and personality traits on different creativities: A dual-process theory account. Psychology of Aesthetics, Creativity, and the Arts. Advance online publication. doi:10.1037/a0026241

Lubart, T. I. (1994). Creativity. In J. R. Sternberg (Ed.), Thinking and problem solving (pp. 289-332). San Diego, CA: Academic Press.

Maslow, A. (1968). Toward a psychology of being. New York: Van Nostrand.

Matheson, D., \& Grosvenor, I. (Eds.) (1999). An Introduction to the study of education. London: David Fulton Publisher.

Matthews, B. (2006). Engaging education: Developing emotional literacy, equity, and co-education. McGraw-Hill Education: Open University Press.

McCann, M. (2005). Our greatest natural resource: Gifted education in Australia. Gifted Education International, 19(2), 90-107. http://dx.doi.org/10.1177/026142940501900203

McVey, D. (2008). Why all writing is creative writing. Innovations in Education \& Teaching International, 45(3), 289-294. http://dx.doi.org/10.1080/14703290802176204

Meeker, M. (1985). Structure of intellect learning abilities test. Los Angeles: Western Psychological Services.

Meintjes, H., \& Grosser, M. (2010). Creative thinking in prospective teachers: the status quo and the impact of contextual factors. South African Journal of Education, 30, 361-386.

Messman, T. R. (1991). From antique books to word processing: A whole-language approach inspires creativity in young gifted authors. Illinois Council forthe Gifted Journal, 10, 35-38.

Naderi, H., Abdullah, R., Aizan, H. T., Sharir, J., \& Kumar, V. (2009). Creativity, age and gender as predictors on academic achievement among undergraduate students. Journal of American Science, 5(5), 101-112.

Neethling, K. (2000). The beyonders. In E. P. Torrance (Ed.), On the edge and keeping on the edge (pp. 153-166). Bensenville, IL: Scholastic Testing Service, Inc.

Niu, W. \& Sternberg, R. J. (2003). Societal and school influences on student creativity: The case of China. Psychology in the Schools, 40(1), 103-114. http://dx.doi.org/10.1002/pits.10072

Noddings, N. (2003). Happiness and education. Cambridge: Cambridge University Press. http://dx.doi.org/10.1017/CBO9780511499920

Otto, B. (1991). Creativity in reading and writing are considered in: "Techniques for stimulating story writing among gifted children". Illinois Council for the Gifted Journal, 10, 31-33.

Palaniappan, A. K. (2007). Academic achievement of groups formed based on creativity and intelligence. Paper presented at the 13th International Conference on Thinking Norrköping.

Piaget, J. (2002). The language and thought of the child. London: Routledge.

Pishghadam, R. (2011). Introducing Applied ELT as a new approach in second/foreign language studies. Iranian EFL Journal, 7 (2), 8-14.

Pishghadam, R., \& Zabihi, R. (2012). Life syllabus: A new research agenda in English language teaching. Perspectives, 19 (1), 23-27.

Pishghadam, R., Zabihi, R., \& Norouz Kermanshahi, P. (2012). Educational language teaching: A new movement beyond reflective/critical teacher. Life Science Journal, 9(1), 892-899.

Plucker, J. A., Beghetto, R. A., \& Dow, G. T. (2004). Why isn't creativity more important to educational psychologists? Potentials, pitfalls, and future directions in creativity research. Educational Psychologist, 39(2), 83-96. http://dx.doi.org/10.1207/s15326985ep3902_1

Pollert, L. H., Feldhusen, J. F., Van Mondfrans, A. P., \& Treffinger, D. J. (1969). Role of memory in divergent thinking. Psychological Reports, 25(1), 151-156. http://dx.doi.org/10.2466/pr0.1969.25.1.151

Radja, K., Hoffmann, A. M., \& Bakhshi, P. (2008). Education and capabilities approach: Life skills education as a bridge to human capabilities. http://ethique.perso.neuf.fr/Hoffmann_Radja_Bakhshi.pdf.

Rosenthal, A., DeMers, S. T., Stilwell, W., Graybeal, S., \& Zins, J. (1983). Comparison of interrater reliability on the Torrance Test of Creative Thinking for gifted and non-gifted students. Psychology in the Schools, 
Ketabi, S., Zabihi, R., \& Ghadiri, M.

20(1), 35-40.

http://dx.doi.org/10.1002/1520-6807(198301)20:1<35::AID-PITS2310200110>3.0.CO;2-Q

Rudowicz, E., Lok, D., \& Kitto, J. (1995). Use of the Torrance tests of creative thinking in an exploratory study of creativity in Hong Kong primary schoolchildren: A cross-cultural comparison. International Journal of Psychology, 30(4), 417-430. http://dx.doi.org/10.1080/00207599508246577

Runco, M. A. (2004). Creativity. Annual Review of Psychology, 55, 657-687. http://dx.doi.org/10.1146/annurev.psych.55.090902.141502

Runco, M. A., \& Albert, R. S. (1985). The reliability and validity of ideational originality in the divergent thinking of academically gifted and nongifted children. Educational and Psychological Measurement, $45,483-501$.

Sak, U. (2004). About creativity, giftedness, and teaching the creatively gifted in the classroom. Roeper Review, 26(4), 216. http://dx.doi.org/10.1080/02783190409554272

Scanlon, J. (2006). Reading, writing, and creativity. Business Week Online, 00077135, 2/23/2006, p. 10.

Smith, D. K., Paradice, D. B., \& Smith, S. M. (2000). Prepare your mind for creativity. Communications of the ACM, 43(7), 110-116. http://dx.doi.org/10.1145/341852.341870

Spence, S. H. (2003). Social skills training with children and young people: Theory, evidence and practice. Child and Adolescent Mental Health. 8(2), 84-96. http://dx.doi.org/10.1111/1475-3588.00051

Sternberg, R. J. (1997). Intelligence and lifelong learning: What is new and how can we use it? American Psychology, 3(2), 83-100.

Sternberg, R. J., \& Lubart, T. I. (1996). Investing in creativity. American Psychologist, 51, 677-688. http://dx.doi.org/10.1037/0003-066X.51.7.677

Struthers, C. W., Menec, V. H., Schonwetter, D. J., \& Perry, R. P. (1996). The effects of perceived attributions, action control, and creativity on college students' motivation and performance: A field study. Learning and Individual Differences, 8(2), 121-139. http://dx.doi.org/10.1016/S1041-6080(96)90029-1

Sturgell, I. (2008). Touchstone texts: Fertile ground for creativity. Reading Teacher, 61(5), 411-414. http://dx.doi.org/10.1598/RT.61.5.5

Taylor, C. W., \& Sacks, D. (1981). Facilitating lifetime creative processes-A think piece. Gifted Child Quarterly, 25(3), 116-118. http://dx.doi.org/10.1177/001698628102500306

Torrance, E. P. (1966). Torrance tests of creative thinking (Research ed.). Princeton, NJ: Personnel Press.

Torrance, E. P. (1988). The nature of creativity as a manifest in testing. In R. J. Sternberg (ed.), The nature of creativity: Contemporary psychological perspectives. Cambridge: Cambridge University Press.

Torrance, E. P. (1992). A national climate for creativity and invention. Gifted Child Today, 15(1), 10-14.

Torrance, E. P. (Ed.). (2000). On the edge and keeping on the edge. Bensenville, IL: Scholastic Testing Service, Inc.

Urban, K. K., \& Jellen, H. G. (1996). Test for creative thinking-drawing production (TCT-DP). Netherlands: Swet \& Zeitlinger.

Von Eschenbach, J. F., \& Noland, R. E. (1981). Changes in student teachers' perception of the creative pupil. The Creative Child and Adult Quarterly, 8, 169-177.

Vygotsky, L. (1986). Thought and language. Cambridge, MA: The MIT Press.

Walker, J. C. (1999). Self-determination as an educational aim. In R. Marples (Ed.), The aims of education. London: Routledge.

Wang, A. Y. (2011). Contexts of creative thinking: A comparison on creative performance of student teachers in Taiwan and the United States. Journal of International and Cross-cultural Studies, 2(1), 1-14.

WHO (1999). Partners in life skills education: Conclusions from a United Nations inter-agency meeting. Geneva: Department of Mental Health, Social Change and Mental Health Cluster, WHO.

Zachopoulou, E., Trevlas, E., \& Konstadinidou, E. (2006). The design and implementation of a physical education program to promote children's creativity in the early years. International Journal of Early Years Education, 14(3), 279-294. http://dx.doi.org/10.1080/09669760600880043 